European Journal of Turkish Studies

Social Sciences on Contemporary Turkey

4 | 2006

THEMATIC ISSUE

The social practices of kinship. A comparative perspective

\title{
Kinship and Transborder Exchange at the Bulgarian-Serbian border in the second half of the $20^{\text {th }}$ century
}

\section{Galia Valtchinova}

\section{OpenEdition}

\section{Journals}

Electronic version

URL: http://journals.openedition.org/ejts/607

DOI: 10.4000/ejts.607

ISSN: $1773-0546$

Publisher

EJTS

Electronic reference

Galia Valtchinova, «Kinship and Transborder Exchange at the Bulgarian-Serbian border in the second half of the $20^{\text {th }}$ century », European Journal of Turkish Studies [Online], 4 | 2006, Online since 05 March 2015, connection on 16 February 2020. URL : http://journals.openedition.org/ejts/607 ; DOI : 10.4000/ ejts. 607 


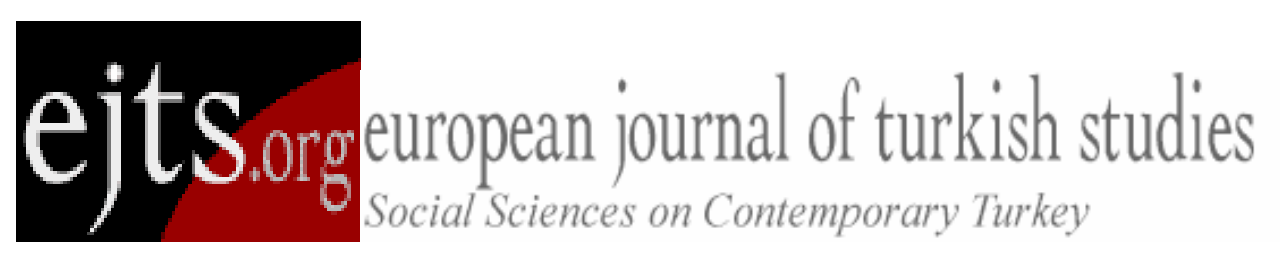

Citation : Valtchinova, Galia (2006) 'From 'Divided Brothers' to 'Liberal Market”, European Journal of Turkish Studies, Thematic Issue $\mathrm{N}^{\circ} 4$, The social practices of kinship. A comparative perspective, URL :

http://www.eits.org/document607.html

To quote a passage, use paragraph (§).

\title{
Kinship and Transborder Exchange at the Bulgarian-Serbian border in the second half of the $20^{\text {th }}$ century
}

\author{
Galia Valtchinova
}

\begin{abstract}
The paper explores the nature and the varieties of transborder encounters on the Bulgarian-Serbian border during socialism and the first post-socialist decade. It offers some facts, and analyzes processes showing what happens when family and kinship have been politicized and manipulated, both on the level of existing structures and as symbols. A historical sketch and an overview of the local structures of kinship provide avenues for understanding the importance of the uses of kinship in a border society and the discourse of 'being the same kin' with people on the other side of the border. The ritual and effective uses of kinship in the peculiar conditions of State socialism are analyzed in the second part of the paper. The third and most lengthy part is dedicated to the post-socialist transformations in the visions of kinship and to some patterns of the use of kin in the context of 'liberal market' economy. I hope having shown that the visions of how to 'use' of family ties - and whether to use them, or not could considerably change over time, especially when there was an ideological and political pressure to do this. Thus in late socialist period, the ideology and images of kinship were used by the communist State in order to counter practices like black market or border petty trade that could not be dissolved in the ideological dogmas. The moralization and politicization of kinship promoted under socialism, but also in the pre-communist period, had an impact on the development of transborder trade in recent years: in lieu of the expected 'ethnic' networks based on a working kin system, the booming transborder trade and smuggling led to the constitution of transethnic networks between ethnic Bulgarians and local Roma. The latter assumed the tasks that both the discourses of kinship and the socialist value system tended to blame as shameful. The recent developments under review call for a more careful consideration of what kind of 'family', for what kind of 'networks', are used during a post-socialist transition.
\end{abstract}


Citation : Valtchinova, Galia (2006) 'From 'Divided Brothers' to 'Liberal Market”, European Journal of Turkish Studies, Thematic Issue $\mathrm{N}^{\circ} 4$, The social practices of kinship. A comparative perspective, URL :

http://www.ejts.org/document607.html

To quote a passage, use paragraph $(\S)$

This is a case study of the uses of kinship in transborder exchange and 'trade' in one of the numerous ambiguous border areas in the Balkans. On the westernmost edge of Bulgaria, the small area of Znepole, divided between Bulgaria and Serbia after World War One, is dominates by the town of Trun. Drawing on fieldwork carried between 1997 and 2000 in a neighborhood ${ }^{1}$ of Trun, the paper focalises on the local practices and images of trans-border contact and exchange between kin. I will ask how transborder ties of kinship - bonds that have been forcibly severed or dying for decades are made meaningful and used by local people during socialism and in the first post-socialist decade. More specifically, I will ask how and if 'kinship' and the 'family' have influenced the petty trade and smuggling activities which have been part of everyday occupational activities for most of the local people in the nineties.

[2] Several issues are intertwined in this study. One of them is the question of the mobilization of kinship ties in key moments of social and economic change (...): perhaps it is most intimately related to the general theme of 'taking risk in family'. Another issue is the thickness of 'market' and the living realities like open-air market and trading in late socialist and post-socialist contexts (Hann 1990; Sik, Wallace 1999). Yet another cluster of questions develops around the symbolic uses of kinship (Herzfeld 1997: chap.2): why, in what contexts, what kind of actors has recourse to the vocabulary of kinship, and for what goals. Finally, last but not least, the issues of 'market' and 'kinship' intersect in an important point: morality. Following a path traced by other anthropologists (Hann, Bellér-Hann 1998, 2000; Mandel, Humphrey 2002), I will try to explore the intertwining of kinship, market/trade and morality.

[3] I start by providing a brief historical overview and introducing the local case from the viewpoint of kinship structures attested in the Central Balkans. The central question of trans-border contact and exchange will be tackled from two sides: a) kinship bonds and networks, and their practical as well as symbolic uses; $b$ ) the shifting definitions and understandings as to the nature of market, and accessorily of transborder exchange. They correspond to the two core parts of the paper: the first is dedicated to the formation of transborder networks and their manipulation by the

${ }^{1}$ I use the term in both its local traditional meaning of mahalla (one speaks of the mahalla of Barinci), and in the sense it was used by Arjun Appadurai's, referring to a distinctive spatial structure of social life which has its own identity and the ability to reproduce itself (Appadurai 1996, chapter 8). 
Citation : Valtchinova, Galia (2006) 'From 'Divided Brothers' to 'Liberal Market”, European Journal of Turkish Studies, Thematic Issue $\mathrm{N}^{\circ} 4$, The social practices of kinship. A comparative perspective, URL :

http://www.ejts.org/document607.html

To quote a passage, use paragraph $(\S)$

State; the second one - to the different ideologies of 'market' and exchange. In conclusion, I show how the notion of morality was played by various actors with regard of both economy and kinship.

\section{I. 'Border society' and kinship in the $20^{\text {th }}$ century Western Bulgaria}

\section{Setting the stage: historical overview}

[4] Trun is the main town of the cultural micro-region of Znepole, which emerged as a cultural unit in the late Ottoman period. At the Liberation (roughly 1878)2 ${ }^{2}$, the local population was torn between two national identities, the Serbian one and the Bulgarian one, both of which targeted the local in their respective enterprises of essentialization of the local culture. The questions of 'ethnic' identity and loyalty of the local population were raised after every military clash, starting with the Serbian-Bulgarian War (October 1885), the Balkan wars (1912/13), and especially after the Great War (1914-1918), at the outcome of which part of Znepole region was annexed to the Kingdom of Serbs, Croats and Slovenes. The new borderline established by the Treaty of Neuilly (November 27 , 1919) run through villages, hamlets and even houses, leaving members of the same family in two different states. The area annexed to Serbia came to be known as the 'Western Marches' [Zapadni pokrajnini], and part of its population has chosen to join Bulgaria where they became known as 'refugees'3. During the Interwar period, the population of the 'Western Marches' was considered as 'purely Serbian'; various measures were taken to impose or enforce a switch from 'Bulgarian' to 'Serbian' identity. Despite incidents however, border crossing was an everyday reality for many during the Interwar period.

[5] In 1941 Bulgaria, an ally of the Axis, was allowed to 'recover' and occupy the areas annexed to Serbia 20 years earlier. Enjoying again free circulation throughout the ancient Znepole area, people from Trun visited the 'Western marches', enlivening the feelings of proximity and reviving the almost severed family ties ${ }^{4}$. After the communists seized power, people from the

2 The area in question knew two 'liberations' from Ottoman rule, both in the framework of the Russian-Turkish war of 1877-78: the first one was by Serbian forces (December 1877), the definitive one by Bulgarians (May 1879).

${ }^{3}$ After WW 1, two groups of refugees Bulgaria flowed to Bulgaria: a larger one coming from what has become Northern Greece (mainly from Greek Macedonia), and the significantly smaller one (estimated between 12000 and 20000 people) of the so-called zapadnopokraintsi,) from the Western Marches. It should however be kept in mind that in terms of 'displacement of population', those refugees who moved only several decades of $\mathrm{km}$. away from their home places do not fit the contemporary mass media-enhanced imaginary of refugees who cross continents and oceans.

${ }^{4}$ I met this kind of discourse among most of my elderly interviewees from Trun. Roughly a quarter of those interviewed acknowledged having kin, having been born or having lived for some time in the 'Western Marches'. 
Citation : Valtchinova, Galia (2006) 'From 'Divided Brothers' to 'Liberal Market”, European Journal of Turkish Studies, Thematic Issue $\mathrm{N}^{\circ} 4$, The social practices of kinship. A comparative perspective, URL :

http://www.ejts.org/document607.html

To quote a passage, use paragraph (§)

'Western marches' who were active supporters of the anti-fascist Resistance have been massively recruited into Trun's new administration and police. Marriages of people from the Bulgarian and Serbian parts of Znepole region have been encouraged. All this made it possible to keep the border control very relaxed during the first post-war years. Retrospectively, local people use to lump together the war period and the first post-war years (roughly, the period going from 1941 to 1947/48) designing it as 'when the border was open'.

[6] The border was 'closed down' in June 1948, when political relations between Bulgaria and Yugoslavia were broken ${ }^{5}$. In communist Yugoslavia, a 'Bulgarian minority' option was made available to people living near the Serbian border [the Western Marches'], who could claim a 'Bulgarian' identity and attend 'Bulgarian' primary schools. However the 1948 political and ideological strife between the two States made such a choice difficult to sustain. Border crossing was criminalized by the Bulgarian communist authorities and condemned as both anti-communist act and national treason. For at least a decade any border crossing was an 'illegal' one, and perpetrators risked being shot on the spot. Nevertheless, border crossing increased: for the locals, it was the shortest way for 'escaping to capitalist West', using family connections in Serbia and Yugoslav passports. Between late forties and late eighties, Trun border area - as many others where the opposing 'world systems' of the Cold war came in touch - was under military and police control, aimed at preventing such escapes $^{6}$. Repressions on relatives left in the country were another, perhaps more effective tool for dissuade potential 'fleers'. As a rule, the families of fugitives were displaced and re-settled in remote regions, mostly in the extreme North-East of Bulgaria, near the Romanian border. Such measures could not stop illegal border crossing: most of the success stories of local people abroad started with 'escape' into the former Yugoslavia, and ended in Western Europe. In time, border control softened and special, highly ritualized forms of transborder exchange started to be regularly practiced: the so called trans-border fairs (see infra). Locally, these gatherings were a test for the use of 'kinship' and new, softer strategies for improving one's standing and condition without fleeing away from Bulgaria.

\footnotetext{
5 It followed closely the abrupt change in the post-war power balance of internationally renowned communist leaders: the 'quarrel' between Stalin and J. B. Tito which led to the first deep division within the 'communist block' (June 28, 1948). It should be reminded however that, unlikely the dominant Western images of Tito's Yugoslavia as close to the communist world, and the successful efforts of domestic elites at building an image for Yugoslavia as a leader of the 'Non-Aligned World' (Gupta 1992), Bulgarian powers considered the SFR of Yugoslavia a 'capitalist State'.

${ }^{6}$ For the multiple and deep effects of military and police control on everyday life of border population, affecting the structure of kinship (cf de Rapper, Deslondes and Roux (2000: 205-08); Green, King (2001 : 278-85) (both for the GreekAlbanian border), and Berdahl (1999) (for the German-German border)).
} 
Citation : Valtchinova, Galia (2006) 'From 'Divided Brothers' to 'Liberal Market”, European Journal of Turkish Studies, Thematic Issue $\mathrm{N}^{\circ} 4$, The social practices of kinship. A comparative perspective, URL :

http://www.ejts.org/document607.html

To quote a passage, use paragraph (§)

\section{Kinship in the divided Znepole area: realities, ideology and discourses}

[7] The local society ${ }^{7}$ is structured around nuclear families, which are related in larger operational networks in a variety of ways. One of them was the extended family: Trun was one of the rare Bulgarian regions with a concentration of households and families of zadruga type, attested over the late $19^{\text {th }}$ and until the mid-20th century ${ }^{8}$. As South-Slavic zadruga in general, these extended families were characterised by common dwelling of three generations (as a rule, a cluster of individual families made of the old parents, of their married sons with their wives and children, plus the unmarried daughters), and common ownership of lands and pastures ${ }^{9}$. The input of work from each member was ruled by the common (family) interest, according to an elaborate scheme of family needs and intra-family division of work (Rheubotton 1996).

[8] Occupation and repartition of work in an economy of subsistence in a poor mountainous area have to be carefully considered to understand that other varieties of extended household and family networks may form, parallel to the zadruga, in the area in question. In Trun and the surrounding villages, a substantial part of the younger male population was involved in seasonal labour activities that required distant migration and made for the scarcity of able-bodies male workers for most of the year. Large-scale migration of the male population far away from home was attested already in the $19^{\text {th }}$ century and up to the interwar period, when political constraints made for its transformation. It followed two distinctive paths: a) seasonal agricultural wage labour, and b) construction works, an occupation which provided wider employment and drew most of the local manpower to Central Serbia and nowadays Romania. By the last quarter of the $19^{\text {th }}$ century most of the males in active age lived up the rhythm of the itinerant masons' groups, which imposed to them being far from home for between eight and ten months a year. This created distinctive patterns of

\footnotetext{
${ }^{7}$ For the purpose of this paper, I restrict the 'local society' - which includes a recent but fast growing Roma population to those who identify themselves as Bulgarians: they constitute the local society in the longue durée that counts for the processes under study.

${ }^{8}$ Here 'concentration' does not mean that the majority of the local population lived in such families but only that they were more frequent than in other parts of the country. It is difficult to deduce the real impact of the extended family from widespread assertions of my local informants that 'zadrugas' were common in Trun and their extinction was recent; they point however to the fact that such family was socially accepted as an ideal-type (cf. Paleczek (1989) for a similar situation in Turkey).

${ }^{9}$ For the place of zadruga in local society cf. Pesheva (1960). For South Slavic zadruga (or communal family) more generally see Byrnes (1976); Halpern (1958), Halpern and Anderson (1970), and the discussion in Todorova (1993: 133174). As far as Bulgaria is concerned, the latter's study on large families shows a concentration of zadruga in the Western strip of the country and albeit less so, in its Southern parts (Todorova : 149-51; Todorova: 148).
} 
Citation : Valtchinova, Galia (2006) 'From 'Divided Brothers' to 'Liberal Market”, European Journal of Turkish Studies, Thematic Issue $\mathrm{N}^{\circ} 4$, The social practices of kinship. A comparative perspective, URL :

http://www.ejts.org/document607.html

To quote a passage, use paragraph (§)

kinship solidarity and task rotation. Since the 1920s, numbers of those masons settled in Sofia, bringing their families: the common opinion was that the 'Trun masons' were especially effective in networking, as people who knew how to take advantage of their work organization and large families in order to insure relative economic prosperity and upward social mobility.

[9] The death of the zadruga was a gradual process that started in the $19^{\text {th }}$ century, reaching its peak in the early $20^{\text {th }}$ century and the Interwar period ${ }^{10}$. The last extended families disappeared in the 1950, under the effect of socialist urbanization. Land partition and inheritance of land were central to this process: the issue of land property and the right to inherit land was raised again and again, in a myriad of cases of family divisions, leading to various ad hoc adjustments between the local custom (according to which female descendants could not have a share of family lands or house) and civil law (modern Bulgarian law stated similar, if not completely equal, right of inheritance of sons and daughters). Some recent local studies suggest that 'sisters' who had been disadvantaged as 'daughters' could claim their shares (miraz) from brothers who had taken full advantage of the privileged position of 'sons', especially in land partitions in the decade before the political change of 1944. Such women are called mirazcijka [the one who looks for her share], a negatively connoted word that clearly indicates the low level of social acceptance for this practice. Perhaps it is not unusual that such cases are explained by the husband's cupidity: then the 'sister's husband' is stigmatized as mirazčija - a term indicating one seeking to enrich himself through his wife's wealth. In a similar way, in other Southern Slavic societies it was believed that the brothers' wives brought about the destruction of a zadruga (Balikci 1965). Such popular interpretations point to a process working against agnatic relationships - a process that undermines the bonds between brothers, or between siblings, in favour of [at least possible] coalitions between affinal kin. In the Trun case, one have good reasons to expect much less tensions between men related through women - a bond illustrated by the figure of badzanaks, the sisters' husbands - than between siblings.

[10] The division of Znepole area made this picture still more complex. First, the re-drawing of the political frontier made for a radical shift in national allegiances of those who remained 'on the other side of the border': during the Interwar period, the 'Serbianism' of people living in the 'Western Marches' had to be shown in a variety of ways: name-change, switching from their vernacular to 
Citation : Valtchinova, Galia (2006) 'From 'Divided Brothers' to 'Liberal Market”, European Journal of Turkish Studies, Thematic Issue $\mathrm{N}^{\circ} 4$, The social practices of kinship. A comparative perspective, URL :

http://www.ejts.org/document607.html

To quote a passage, use paragraph $(\S)$

literary Serb in schools and in public places, and other appropriated behaviour. In this vein, entitlement to land property that happened to be 'on the other side' of the border became source of bitter conflicts: working such land required frequent border crossing and constituted either the background for a change of identity (from 'Bulgarian' to 'Serbian'), or a potential danger to life (if insisting on 'Bulgarian-ness') ${ }^{11}$. Thus, large and potentially powerful kinship networks were made inefficient already before the outbreak of the Second World War. More, through the issue of division of common land property that accompanied the extinction of zadrugas, the process of division of extended families was politicized and used in the Bulgarian-Serbian rivalry over the identity of the population in the Znepole area ${ }^{12}$. In this way border crossing was still complicated by the issue of land property and division of large families whose different branches were residing in two different States. It could be expected that, when 'land' became 'territory', to use Deema Kaneff's (1998) formula, traditional structures of kinship were no more functional, at least not in the way they used to be. Becoming a matter of national[ist] politics and discourses of power already in the 1920s, after the change of regime the role of kin in border crossing and exchange became a truly political and ideological issue. It was even more so after the pro-Western opening of Yugoslavia in the early 1960s, which contrasted to the hard-line Moscow orientation of Bulgaria and made 'Yugoslav' identity appear attractive to an increasing number of people 'on this side' of the border. Relations of kinship with people 'over the border' were filed by the local (and Party) administration in order to prevent any attempt to use them.

[11] In such a way, an avenue for political considerations in the use of kinship was open that would influence both local politics and kinship networks. Perhaps more important was that kinship its vocabulary, its symbols and its existing structures - was politicized and manipulated. In the next part, I will compare practical uses of kin networks in interactions between people from both sides of the border to the symbolic use of 'kinship' and 'divided families' in State-sponsored discourses.

\footnotetext{
11 The local press from the Interwar period reports numerous cases of peasants working their land that have been spoiled during border crossing, or even maltreated, by Serbian border guards (the data are summarized in Valtchinova (1999: 131-33), with literature). Informed by a wounded nationalism, such data have to be taken with caution; nevertheless they suggest that the border crossing was a source of painful and humiliating experiences. The first time that the locals had to use identity papers was also related to the border-crossing of those who owned land property 'on the other side of the border': they needed special permits in order to work them, as well as for any transaction with their land.

12 The use of zadruga, and accessorily of the slava ritual, as an argument for claiming 'ethnic identity' of a given population, corresponds to the same logic: cf. Todorova (1993a); Hristov (2002).
} 
Citation : Valtchinova, Galia (2006) 'From 'Divided Brothers' to 'Liberal Market”, European Journal of Turkish Studies, Thematic Issue $\mathrm{N}^{\circ} 4$, The social practices of kinship. A comparative perspective, URL :

http://www.ejts.org/document607.html

To quote a passage, use paragraph (§)

\section{The uses of 'kinship' in practices and discourses, 1960s-1990}

[12] Transborder relations and exchange between kin through the Bulgarian-Serbian border took a variety of forms, from everyday work and individual visits that required border-crossing to vast collective gatherings. As a rule, most of them were rendered impracticable, or criminalized, either by one of the bordering States, either by both of them. It was most clearly so when such exchange was related to an economic activity, or some kind of entrepreneurship: due to increasingly strict border regulations, the latter was soon or late qualified as 'black market' and/or 'illegal economic activities'. Hereafter, I will focus on a specific form of exchange, the trans-border fairs, which were the dominant form of 'lawful' trans-border exchange over a half of century.

\section{The 'fairs': from religious feast to political manifestation}

[13] By the time of my fieldwork in the Trun area, the fairs [săbor, pl. săbori] used to be associated to the ritualized 'traditional-style' meetings, held till the late eighties, of kinfolk living in the two countries, whose families generally speaking have been separated by the border of 1920. The 'fairs' were depicted in a vocabulary of kinship and of nostalgia for the past. Their history could be traced back to the late twenties, when they were organized only by people identifying themselves as Bulgarians, on both sides of the then new border. Practiced only in some of the divided villages, they were designed as a peaceful form of local people's protest against the division: from this time on, 'divided brothers' becomes a main metaphor. They took place during religious feasts, on the commemoration day of the village's patron saint, a fact that maintained blurred the boundary between the public (and civil) event and the religious event which was the cultural background of the 'fairs' (Vryonis 1983). During the Interwar period, the 'fairs' have quickly become arenas of nationalist clashes especially when the anti-Serbian manifestations fuelled the mutual resentment of groups of young men, already nervous about their 'rights' over local girls because of the tightening of the matrimonial market on both sides of the border. The violence that accompanied transborder exchange in this period was also related to the negotiation of symbolic capital: some of the hottest arguments started from quarrels on the importance of the patron saint who was celebrated, and more the saint was important in the Bulgarian or Serbian national perspective, more the whole affair could 
Citation : Valtchinova, Galia (2006) 'From 'Divided Brothers' to 'Liberal Market”, European Journal of Turkish Studies, Thematic Issue $\mathrm{N}^{\circ} 4$, The social practices of kinship. A comparative perspective, URL :

http://www.ejts.org/document607.html

To quote a passage, use paragraph (§)

turn to a political one ${ }^{13}$. The youth's battles brought occasionally to murders, and when these occurred, the gatherings were suspended; however such a decision was rarely maintained for more than a year. Some 'fairs' of the interwar period turned the respective villages into places of trauma and memory. This is the case of the village of $S$., where a checkpoint (the unique one for the whole region), has been established, that 'fairs' were held again.

[14] With World War Two and the political and social transformations following it, the practice of transborder fairs has been interrupted for almost two decades. Revived in 1960, transborder fairs featured a still more sophisticated use of kinship. They consisted in ritualized meetings, once or (rarely) twice a year, of Bulgarian and Serbian/Yugoslav citizens who were (or claimed to be) related by family ties, in the no man's land between the two states. As a rule, they occurred beyond all the circles of military control, in the no-man's land on either side of the frontier which here - as elsewhere in the Balkans, was made apparent as a thick line of ploughed soil. The 'fairs' developed along the borderline, sometimes continuing throughout several $\mathrm{km}$, spreading over the bare land which was left on each side of the borderline. Officially, however, fairs were hosted alternatively by each country, the issue of 'hosting' being important with regard to responsibility for eventual 'incidents'. The latter was quite a delicate issue: the police patrolled by both sides, the Bulgarian one paying attention to the issue of 'anti-communist propaganda' which the 'Serbs' were supposed to pursue.

\section{Border-crossing and the politics of kinship}

[15] It is worth noting the different perception between people who used to come on the fairs from the two sides of the border. My interlocutors from Trun evoked their experiences from those fairs mainly in terms of access to commodities which they had never previously seen or could never purchase. The local 'boss' put his memories in the following way: 'they were damned traders, the Serbs, and evoking that we were kin did not help us very much ... Thinking now what I had to pay for a pair of shoes and a K-way!' Significantly, however, another way of reminding these encounters was in terms of fear (or shame) of being recognized by acquaintances or relatives who had 'escaped' to Serbia and took advantage of the event to contact their relatives. Such encounters could result in

${ }^{13}$ For instance, two of the fairs were held on the St. Cyril's and Methodius' commemoration day what - since those saints were associated with Bulgarian schools and the entire cultural politics - was especially outrageous to the Serbian administration. The latter opposed to these two saints St. Sava, considered as 'Serbian national saint' of and patron of the Serbian school and education. 
Citation : Valtchinova, Galia (2006) 'From 'Divided Brothers' to 'Liberal Market”, European Journal of Turkish Studies, Thematic Issue $\mathrm{N}^{\circ} 4$, The social practices of kinship. A comparative perspective, URL :

http://www.ejts.org/document607.html

To quote a passage, use paragraph (§)

serious troubles for the customer. Attempting to delineate a more general 'Bulgarian viewpoint' one can subsume that the discourse of kinship served to wrap up more practical considerations about access to Western-style commodities - and in some cases, to the 'West' as a location, trough 'escape'.

[16] On the other hand, people who have attended these fairs coming from Serbia remember their experience much more in terms of emotional bonds and positive use of kin ties. The feelings and memories of people coming from the Serbian side of the border concentrated upon a different kind of experience: my interviewees ${ }^{14}$ evoked mostly the moment of recognition of relatives from which they have been separated for decades, and the act of taking meals together.

[17] Putting aside the activities of entitled or occasional traders - after all, a 'fair' was by definition a place for trading - the other forms of exchange were quite limited. It involved neither a movement far away (in the sixties, people from the Trun area usually went to the fairs on foot), nor a real change of State (fairs were located in a tiny strip of land alongside the borderline). The exchange of information was highly controlled; the police watching made it difficult to exchange any practical information about how people lived 'outside'. Talking with a 'Yugoslav citizen' about his/her life in 'Tito's Yugoslavia' or experience of 'abroad' was a risky enterprise: the Bulgarian authorities considered such talks as 'anti-socialist propaganda'. Tête-à-tête talks were supposed to lead to planning one's 'escape into Serbia', and such things could hardly be discussed when taking collective meals. Only the invocation of family memories was tolerated in the public space. As a rule, during the fair people kept in groups and any attempt at separating oneself from the kin-based or neighbourhood-based group one was attached to might be considered as an 'attempt at illegal border-crossing'. However, times and again it happened that when held on the Yugoslav side of the border, some young men or women did not return by the closing down of the fair. The 'non-returnees' were officially presented as 'victims of Serbian machinations', any suggestion of operating kin networks was occulted. Such events were either covered, or could justify the immediate suspension the fair. The more ritualized the 'crossing of the border' was, the less family ties and practical use of kinship should surface.

14 I could collect information on this topic only from six persons during a single field trip I made in the Serbian villages of Zvonci and Trunska Osikovica, in August 2002. 
Citation : Valtchinova, Galia (2006) 'From 'Divided Brothers' to 'Liberal Market”, European Journal of Turkish Studies, Thematic Issue $\mathrm{N}^{\circ} 4$, The social practices of kinship. A comparative perspective, URL :

http://www.ejts.org/document607.html

To quote a passage, use paragraph (§)

[18] Thus, control exercised by the socialist State contributed towards the ritualization of transborder exchange. Trying to promote memories of the past and the kinship ties as the only basis for interaction and lawful exchange, one and the same move had two results: essentializing kinship and capturing it in a traditionalist discourse centred on the past. This attempt at a State management of practices and discourses of kinship for two contradictory goals - justifying transborder gatherings, and preventing people (at the Bulgarians) from engaging in effective exchange - led to a conflict between the literal and the metaphoric use of terms and discourses of kinship. Progressively, the background was created for a possible clash over meanings of 'kinship' and 'family' - and over identity broadly speaking, a clash that would resonate on a deeper level; I hint on this process in the last part of the paper.

\section{Changing meanings: from 'transborder fairs' to transborder market}

[19] These trans-border fairs were intended to provide ground for highly controlled exchange between kinsmen living on both sides of the border. In the new format of the transborder fairs, any kind of exchange was under strong control of both States' authorities. Access to the fairs remained for years limited to the locals and to those able to demonstrate they had kin in the area. By the end of the 1960s, however, these meetings had become very popular, drawing people from throughout Bulgaria. This was perhaps inevitable: transborder fairs represented a kind of 'first contact' with the West and any activity associated with them was invested with high symbolic value.

[20] The general softening of the policies of socialism in the seventies made for some significant shifts in the meaning of transborder fairs. First, they were no more arenas of incessant police watch: on the Bulgarian side, control became more discrete and, due to the flux of visitors, less effective. Initially designated only to the population of the border areas, the fairs attracted more and more people from 'inland' Bulgaria, people whose main interest was trading and/or purchasing commodities. As having a one-day border permits remained the precondition of attending a transborder fair, the emission of such permits tended to become a kind of administrative industry: relatively few people were refused permits. Putting together numbers of people who did never know each other had as a result to transform what was deemed to be the raison d'etre of the fairs: reasserting family ties and sharing memories about divided branches of former extended families that have been left in two different countries. Starting from this time, the fairs were increasingly perceived 
Citation : Valtchinova, Galia (2006) 'From 'Divided Brothers' to 'Liberal Market”, European Journal of Turkish Studies, Thematic Issue $\mathrm{N}^{\circ} 4$, The social practices of kinship. A comparative perspective, URL :

http://www.ejts.org/document607.html

To quote a passage, use paragraph (§)

as places where Bulgarians could meet and exchange with people who have experienced 'capitalism'. For the majority of those who gathered there, the fairs were an occasion to get in touch with 'Western goods' and (through illustrated magazines) with Western life-styles. The issue of 'pornography' emerged as a special concern: the seizure of 'pornographic' images and magazines smuggled by (as a rule) Yugoslav citizens was punished by interdicting access to the fair. The image of 'the Yugoslav' (a male) smuggling porno magazines, tapes and sex items to 'deviant' Bulgarians became - and for elderly Trun people it was still true in the mid nineties - a sort of negative icon associated with the perils of 'capitalism' and free exchange. This reminds the situation depicted by Hann and Beller-Hann's (1998; 2000: 82-91) in North-Eastern Turkey: once the border between Turkey (Lazistan) and former Soviet Union (Georgia) had been opened, the petty trade and smuggling of outdated Soviet goods cleared the way to merchandizing sex and to prostitution. So the local society studied by the Hann - which, for me, takes the same structural place as the Bulgarians in our case - perceived transborder trade as deeply immoral and socially disrupting activity. Despite the magnification of the 'West' obvious in our late-socialist context, a similar idea of immorality of 'free exchange,' embodied in immoral men trading images and attributes of 'sex', was taking shape.

[21] The transborder fairs declined and gradually disappeared in the eighties. Vested in the ideological framework of kinship and supported by discourses of and 'divided brothers', they were to disappear once this discourse proved inadequate to the realities of exchange and new strategies of making use of kin networks. Their disappearance signalled a deep change in attitudes to 'market' and commercial activities that State socialism had condemned as both unlawful and immoral. The vacuum left by 'transborder fairs' was promptly filled by 'black market'. Places where the fairs have been held as the village of $S$., where the only for the Znepole area border-crossing checkpoint functioned since the twenties, became zone of 'illegal traders'. Years before the change of the regime, legal constraints against 'black merchants' had no more effect: soon the legalist discourse which was obviously contradicted by practice, was replaced by a moralizing discourse that denigrated transborder trade as 'immoral'. What we face here, as Hann and Beller-Hann (1998) did in Turkey, is a more or less clear relationship between the weakness of official State ideology and practices, on the one hand, and powerful development of moralizing discourses - on the other one. It seems that de-moralizing petty trade is a solution to which a society - or a State - has recourse every time that it cannot enforce rules upon its members, or its citizens. 
Citation : Valtchinova, Galia (2006) 'From 'Divided Brothers' to 'Liberal Market”, European Journal of Turkish Studies, Thematic Issue $\mathrm{N}^{\circ} 4$, The social practices of kinship. A comparative perspective, URL :

http://www.ejts.org/document607.html

To quote a passage, use paragraph (§)

\section{Blurred boundaries, trans-border trade and the use of kinship in the post-socialist space}

[22] On Bulgaria's Western periphery, the change of regime that took place in late 1989 was felt primarily in what concerned the border and border crossing. In 1990-1991/92, the panoply of border-keeping installations was demolished. With the advent of more liberal economic policies, the Bulgarian borders have been opened and trade relations that were once deemed illegal became normal everyday reality ${ }^{15}$. In Bulgaria as in other ex-communist countries, transition to market economy was accompanied by an economic crisis and brought to growing social inequality and impoverishment of population (Bridges, Pine 1998; Burawoy, Verdery 1999). In these conditions, transborder economies boomed, especially across the Bulgarian-Turkish border (Konstantinov 1995; Prickle 2000), where trading and smuggling became the main survival strategy. Using networks of kinship and confessional affiliation as well as linguistic skills, Turkish and Roma entrepreneurs dominated would-be 'capitalist' economy of towns and whole regions (Konstantinov, Kressel and Thuen 1998; Prickle 2000: 9-11, 15-21). This led to a redistribution of social capital between ethnic groups and, partly, a reversal of hierarchies: 'former outcasts' (Konstantinov, Kressel and Thuen 1998) stigmatized under socialism as 'lazy' or 'inept to work', adapted quickly to the market system and demands, and even found themselves advantaged by some of the characteristics they were stigmatized for: distrust with State authority, relying on informal networks (Stewart 1993: 191-92).

[23] On the Bulgarian-Serbian border, the picture was similar in the sense that transborder trade and smuggling were full-time occupations that an important part of the local population saw as their survival, while a handful of people used the opportunity for lucrative business. In Trun and its area, transborder exchange flourished between 1991 and 1995, in the period when former Yugoslavia was ravaged by the wars. Under the joint effect of war and embargo on Serbia ['rump Yugoslavia'], shortages of edibles and other goods had created a practically unlimited market 'on the other side' and attracted Bulgarian entrepreneurs of various kinds. Local petty-traders and smugglers were especially successful during the second period of the war in Bosnia (1994-95), when the Western embargo on Yugoslavia was at its height. In this period, the main target of transborder trade was petrol: by the mid-1990s, Trun had the reputation of being a 'town of petrol millionaires'. Quantities of petrol and fuel taken from the oil pumps were transported to the border and in the 
Citation : Valtchinova, Galia (2006) 'From 'Divided Brothers' to 'Liberal Market”, European Journal of Turkish Studies, Thematic Issue $\mathrm{N}^{\circ} 4$, The social practices of kinship. A comparative perspective, URL :

http://www.ejts.org/document607.html

To quote a passage, use paragraph (§)

closest Serbian villages in car tanks, in cans and even in water plastic bottles carried on hand. In this way, many locals who had no cars could take part in what has become a truly mass enterprise. For most of the smugglers, this was more of a temporary profit-making activity that could relieve from unemployment: by 1997, Trun had one of the highest unemployment rates in Bulgaria, affecting largely its Roma population.

[24] The latter is an additional element that makes transborder trade appearing similar to what was observed on the Turkish-Bulgarian border and more generally on opening borders with former communist countries. In our case, however, a clash is possible between the expected revival of loosened transborder kinship solidarities and the use of family networks - on the one hand, and massive involvement of Roma population in transborder petty trade. To what an extent the large minority group is prominent on the market and enters in competition with petty traders and smugglers who rely on kin 'on the other side of the border'? The question to ask is to what an extent the bonds between related families on both sides of the border were rebuilt, and whether kinship networks were revived and used (if at all) in order to cope with hardships, in a defensive way, or for market-oriented action. Examining a few cases will help answering the questions.

[25] The first case is N.R., the local 'boss', whose name is known (by 2000) to virtually all inhabitants of Trun. He is proud to be 'the boss' giving employment to many people of his native town; he uses to talk about his enterprise with pride and making use of strongly paternalist discourse. He is also supporting the local church acting as leader of a lay 'church committee' supposed to help the local Christian Orthodox priest but which acts in a very independent way. Since 1999, he is also the informal leader of a revived nationalist organisation founded in the thirties. N. R. has no kin 'on the other side' - at least not one he boasts with - but a lot of acquaintances to whom he refers as 'our brothers behind the border'. His early experience in transborder exchange is central to his orientation to entrepreneurship. In the years of communism, he had followed the road typical for local male youth in the years of industrialisation: engaging himself in construction industry and technical support and becoming resident of Sofia. The acquaintances at his former working place and the network of influential persons he has built and had recourse to when employed in his State enterprise have been of great use when times changed. Once retired from State employment, he engaged in private business, relying on his former colleagues for specialised information and help, and to local population in his native town - for manpower. He employed about twenty local people through legal contract and much more (usually Roma) as daily wageworkers. Despite his emphasis on family 
Citation : Valtchinova, Galia (2006) 'From 'Divided Brothers' to 'Liberal Market”, European Journal of Turkish Studies, Thematic Issue $\mathrm{N}^{\circ} 4$, The social practices of kinship. A comparative perspective, URL :

http://www.ejts.org/document607.html

To quote a passage, use paragraph (§)

values, on help and support due to kin, he clearly avoids building networks with close kin: he is said to be estranged with his two sisters, and never had common business with their husbands or other members of their families. He is proud with the achievements of his son and daughter-in-law, both involved in what he sees as family business. Officially, he had never been involved in transborder trade, and condemned petrol smuggling. Perhaps many of the Roma petty traders were depending on him for wage work.

[26] The second case is M.T., a man is his late fifties when I first met him in 1995. Born from a 'Serbian' mother (from the Western Marches), he had Yugoslav kinsmen whom he knew only at an advanced age, in the eighties. With two 'Bulgarian' parents one of which from a divided border village, his wife had also kin networks in Serbia which seem to be more operational: her mother's brother 'escape' from Bulgaria in the early fifties resulted in harassment of the whole family by the communist regime, but was also a source of pride with 'Yugoslav cousins'. Since the mid-seventies and throughout the eighties, M.T. and his wife have been allowed (with special passports) to pay visits to their kin living in Yugoslavia. They paid visit mainly on ritual occasions: for big Christian holidays (on Easter, Nativity, the patron saint's day of the village or town they visited) or for marking events of the life cycle (a baptism, a wedding or a funeral). Smuggling whatever goods across the border in this period was seen as 'gift-giving' and an exchange of 'gifts'; even retrospectively, M. and his wife carefully avoided speaking of these visits in terms of 'trade', market, or 'business', insisting on the 'reunion of divided family' and cousins. Perhaps M. developed some entrepreneurial activity already in late eighties, parallel to his job in a State socialist enterprise. His first steps (with high risk) in this direction were secured by his agnates: $M$ could rely on his two brothers, one of whom became his associate. After this first private (and partly family) enterprise failed, he turned for help to his bacanak who has been more successful ; the latter was more operational and truly helpful for M.'s son who established his own car retail and trading firm. Nevertheless, if talking respectfully about the bacanak, $\mathrm{M}$. always ranks his brothers before him.

[27] V.K., the former mayor's daughter, a nursing sister and petrol smuggle, is the only case representative of the multitude of local actors which I could identify as 'petty traders' involved in petrol smuggling. Such an identification proved to be quite a difficult one: after 1996 when the 'petrol fever' was definitively over, those people kept very discrete about their trading/smuggling activities and every time I tried to raise the issue before an interlocutor who was reported to, by insiders, as having practiced transborder smuggling, he or she pointed to another one. The following account draws partly on V.K.'s life history, as well as on accounts of her neighbors. 
Citation : Valtchinova, Galia (2006) 'From 'Divided Brothers' to 'Liberal Market”, European Journal of Turkish Studies, Thematic Issue $\mathrm{N}^{\circ} 4$, The social practices of kinship. A comparative perspective, URL :

http://www.ejts.org/document607.html

To quote a passage, use paragraph (§)

[28] VK became 'trader' (as the activity was labeled) in 1995, at a relatively late stage of the 'petrol fever'. By this time, she had permanent job: main nursing sister in the town hospital, what corresponded to a high social status. Perhaps she knew that 'it was not for long time': in her early fifties, retirement was short, and still her salary of failed to provide for her and her old mother's vital needs. Petty trading and smuggling were presented as a purely 'survival strategy', activities she felt as deeply 'shameful' and tried to disguise them to the eyes of neighbors and acquaintances. She started to smuggle petrol, arranging herself to take quantities from an oil-pump located away from the town ${ }^{16}$ and 'not to mix with [vulgar] smugglers', a way to say 'Roma': according to the locals, Roma people were 'the smugglers' par excellence. She had no recourse to kin, despite having relatively close relatives in a nearby Serbian village. Quite the opposite: VK was 'ashamed' to be seen by her relatives doing petty trade, an activity deemed unsuitable for respectful people. As she tried avoiding both family networks and common action with fellow villagers and/or Trun people, she had to be especially inventive in 'border theater' (McMurray 2001:112-19). In a way similar to the smugglers observed on the Moroccan-Spanish border, women smuggling petrol in Serbia had to evaluate carefully their persuasive strategies, leaving no shadow of doubt regarding their 'respectfulness'. Whether a border guard was to be bribed, or to be told complaints of poverty, was a matter of cultural intimacy (Herzfeld 1997) with cultures on both sides of the border, and an essential part of a common knowledge of survival. Another part of this knowledge was that sexuality should be minimized and kept out of the 'arms of persuasion': the discourse of smuggling for survival and assertions that 'we are all the same, brothers in hardship', made selling through sex virtually impossible. Perhaps V.K. was quite conscious that only a thin line separated smuggling women from 'prostitutes': due to repetitive problems with some Serbian border guards, she gave up smuggling ten months later, putting aside however a significant amount of convertible money.

[29] The 'shame' experienced by Bulgarians from Trun when engaging in transborder trade, and especially in smuggling, deserves a closer look. The theme is prominent in the third case of a female smuggler, which points to a possible influence of the 'shame vs. honor' ideological construct. Albeit less explicit, this theme is also present in the two other cases, which require other explanations. To my view, we have to deal here with 'shame' as a social construct of socialism. It has its roots in a specific vision of 'work', as well as in the hierarchy of 'honorable' works and devaluating or 'shameful' ones. According to the Marxist postulate, 'work' was the primary social realization of

\footnotetext{
${ }^{16}$ During 1994-95, the village of G. (with officially ca. 150 inhabitants) had four oil pumps: it was located on the route for
} the border checkpoint of $S$., $5 \mathrm{~km}$. from the latter and $7 \mathrm{~km}$. from Trun. 
Citation : Valtchinova, Galia (2006) 'From 'Divided Brothers' to 'Liberal Market”, European Journal of Turkish Studies, Thematic Issue $\mathrm{N}^{\circ} 4$, The social practices of kinship. A comparative perspective, URL :

http://www.ejts.org/document607.html

To quote a passage, use paragraph (§)

(and approval for being) a good socialist citizen: here 'work' is to be taken in the restrictive sense of regular (and often formalized) wage-labor, typical of socialism ${ }^{17}$. The 'shamefulness' of smuggling and of transborder trade in general - is in our case largely predicated on the socialist value system (Stewart 1993; Konstantinov, Kressel and Thuen 1998) and is based on a more general concept of wealth acquired through trade in the political economy of socialism. Thus a line was drawn between 'essential' smugglers and those who 'did it' because 'in need': the 'shame' of being involved in an improper activity - improper in both moral and legal terms - seems neutralized by transferring on the social 'outcasts' the shamefulness of this activity.

[30] In the same time, talk of 'shame' illuminates another process: the moralization and politicization of kinship. It is the very ideology of kinship and the discourse of 'recreating family ties' developed under socialism that might account for it. As idealized 'kinship' projected onto the past was transformed into powerful discourse of roots and identity, it was difficult for ageing and deeply rooted local people to conceive the good use of kinship through the lens of something that has always been blamed as morally and 'historically' inadequate practice.

\section{Conclusions}

[31] In questioning the variety and the nature of transborder encounters on the BulgarianSerbian border, I have shown that the visions of how to 'use' of family ties - and whether to use them, or not - could considerably change over time. It is true especially when there is an ideological and political pressure to do this. Thus in late socialist period, the ideology and images of kinship were used by the communist State in order to counter practices like black market or border petty trade that could not be dissolved in the ideological dogmas. Coping with crisis and hardships in postsocialist time required local people to involving in new activities associated with freedom and liberal market: open-market and transborder exchange were part of them. Perhaps it was much more an activity for survival than a pursuit of well-being in the Western sense of the word. This led to the proliferation of trading activities that were on the border of law, or illegal even by the standards of liberal economy. The legal status of transborder trade was only a remote concern: in a general manner, the economy of survival leaves little room to issues of law regulation. As other Balkan examples showed, even non-respect for the embargo on Yugoslavia by the neighboring countries was not so much a fact of 
Citation : Valtchinova, Galia (2006) 'From 'Divided Brothers' to 'Liberal Market", European Journal of Turkish Studies, Thematic Issue $\mathrm{N}^{\circ} 4$, The social practices of kinship. A comparative perspective, URL :

http://www.ejts.org/document607.html

To quote a passage, use paragraph (§)

conscious politics, than a strategy of personal or small-group survival in a period of transition and socioeconomic crisis. It was essentially based on kinship but implied also an interchangeable use of professional connections and of 'friends,' a euphemism for ethnic networks. Our Trun fieldwork however defies these general statements. It brings under question the use of family and kinship networks and calls for a more careful consideration of what kind of 'family', for what kind of 'networks', are used in different circumstances. 
Citation : Valtchinova, Galia (2006) 'From 'Divided Brothers' to 'Liberal Market”, European Journal of Turkish Studies, Thematic Issue $\mathrm{N}^{\circ} 4$, The social practices of kinship. A comparative perspective, URL :

http://www.ejts.org/document607.html

To quote a passage, use paragraph $(\S)$

\section{References}

Agelopoulos, Giorgios (2003 [1997]) 'To diktyo Coca Cola - Kashkaval: Ethnotismos, syngeneia kai 'busines' sta Valkania' ['The Coca Cola - Kashkaval network: ethnicity, kinship and business in the Balkans'], in Gefou-Madianou, Dimitra (ed.), Eaftos kai Allos, Athens, Gutenberg, 2003, pp. 343 372 [quoted after the English version presented at the $1^{\text {st }}$ Conference of the ABA, Bankya, 1996].

Appadurai, Arjun (1996) Modernity at Large: Cultural Dimensions of Globalization Minneapolis, University of Minnesota Press.

Balikci, Asen (1965) 'Quarrels in a Balkan Village', American Anthropologist 67/6, part I, pp.14561469.

Berdahl, Daphne (1999) Where the World Ended: Re-Unification and Identity in the German Borderland, Berkeley, UC Press.

Bridges, Sue; Pine, Frances (eds.) (1998) Surviving Post-socialism. Local strategies and regional responses in Eastern Europe and the former Soviet Union, London, Routledge.

Burawoy, Michael; Verdery, K. (eds.) (1999) Uncertain Transition: Ethnographies of Change in the Postsocialist World, New York, Rowman and Littlefield

Byrnes, Robert F. (ed.) (1976) Communal families in the Balkans: The Zadruga. Essays by Philip E. Mosely and Essays in His Honor. Introduction by Margaret Mead, Notre Dame/ London, University of Notre Dame Press.

de Rapper, Gilles; Deslondes, Olivier; Roux, Michel (2000) 'Dimanche à Miras, lundi à Dipotamia: La frontière albano-grecque dans la région de Bilisht et de Kastoria', CEMOTI 29, pp. 199-223.

Green, Sarah; King, Geoffrey (2001) 'Seeing What You Know: Changing Constructions and Perceptions of Landscape in Epirus, NW Greece, 1945 and 1990', History and Anthropology Vol. 12, 3, pp. 255-88.

Gupta, Akhil (1992) 'The Song of the Nonaligned World: Transnational Identities and the Reinscription of Space in Late Capitalism', Cultural Anthropology 7, 1 (February), pp. 63-79.

Herzfeld, Michael (1997) Cultural intimacy: social poetics in the Nation State, New-York-London, Routledge.

Halpern, Joel M. (1958) A Serbian Village, New York, Columbia University Press

Halpern, Joel M.; Anderson, David (1970) 'The Zadruga, a Century of Change', Anthropologica (N.S.) XII, pp. 83-97.

Hann, Chris (1990) 'Second Economy and Civil Society', in Hann, Chris (ed.) Market Economy and Civil Society in Hungary, London, Frank Cass \& Co, pp. 21-44.

Hann, Chris (1993) 'Introduction: Social Anthropology and Socialism', in Hann, Chris (ed.), Socialism. Ideals, Ideologies and Local Practice [= ASA Monographs, 31], London, Routledge, 1-26.

Hann, Chris; Beller-Hann, Ildiko (1998) 'Market, Morality and modernity in North-east Turkey', in Wilson, Thomas; Donnan, Hastings (eds.) Border Identities. Nation and State at international frontiers, Cambridge, Cambridge University Press, pp. 237-262.

Hann, Chris; Beller-Hann, Ildiko (2000) Turkish Region. State, Market and Social Identities on the Eastern Black Sea Coast, Oxford / Santa Fe, James Currey / School of American Research Press.

Hristov, Petko (2002) 'The Use of Holidays for Propaganda Purposes: The 'Serbian' Slava and/or the 'Bulgarian' Săbor', Ethnologia Balkanica, vol. 6, pp. 69-80.

Kaneff, D. (1998) 'When 'land' becomes 'territory': Land privatization and ethnicity in Rural Bulgaria', in Bridger, S.; Pine, F. (eds.), Surviving Post-Socialism. Local strategies and regional responses in Europe and the former Soviet Union, London, Routledge, pp. 21-39. 
Citation : Valtchinova, Galia (2006) 'From 'Divided Brothers' to 'Liberal Market”, European Journal of Turkish Studies, Thematic Issue $\mathrm{N}^{\circ} 4$, The social practices of kinship. A comparative perspective, URL :

http://www.ejts.org/document607.html

To quote a passage, use paragraph (§)

Konstantinov, Yulian (1996) 'Patterns of reinterpretation: trader tourism in the Balkans (Bulgaria) as a picaresque metaphorical enactment of post-totalitarianism', American Ethnologist 23 (4), pp. 762782.

Konstantinov, Yulian; Kressel, Gideon M.; Thuen, Trond (1998) 'Outclassed by Former Outcasts: Petty Trading in Varna', American Ethnologist 25(4), pp. 729-745.

Mandel, Ruth; Humphrey, Caroline (2002), 'The Market in Everyday Life: Ethnographies of Postsocialism', in Mandel, Ruth; Humphrey, Caroline (eds.), Markets and Moralities. Ethnographies of Postsocialism, Oxford, Berg, 1-16.

McMurray, David A. (2001) In and Out of Morocco: Smuggling and Migration in a Frontier Boomtown. Minneapolis, University of Minnesota Press.

Paleczek, Gabriele (1989) 'Household, Field and Market: Turkish families in transition', in Gingrich, A.; Haas, S.; Paleczek, G. (eds.), Kinship, Social Change and Evolution, Wien, F. Berger \& Söhne, pp. 109-121.

Parkin, Robert (2002) 'Administrative Reform, Cross-Border Relations, and Regional Identity in Western Poland', MPI Working Papers No. 47, pp. 1-24.

Pesheva, R. (1960) 'An ancient family feast (celebrating 'svetec' in North-western and Western Bulgaria)' [in Bulgarian], in Ezikovedsko-etnografski izsledvanija v pamet na akad. St. Romanski, Sofia, BAN, pp. 731-754.

Prickle, John (2000) "There are no Turks in Bulgaria': Violence, Ethnicity, and Economic Practice in the Border Regions and Muslim Communities of Post-Socialist Bulgaria', MPI Working Papers No. 25, pp. 1-19.

Schwartz, Jonathan (1996) Pieces of Mosaic. An Essay on the Making of Macedonia, Kopenhagen, Intervention Press.

Rheubottom, David (1996) 'Land, Labour and the Zadruga: The Economic Viability of Peasant Households in Macedonia', Manchester Papers in Social Anthropology, N. 3, pp. 1-24.Sik, Endre; Wallace, Claire (1999) 'The Development of Open-Air Markets in East-Central Europe', International Journal of Urban and Regional Research, Vol. 23, Nr 4, pp. 697-714.

Sik, Endre; Wallace, Claire (1999) 'The Development of Open-Air Markets in East-Central Europe', International Journal of Urban and Regional Research, Vol. 23(4), 697-714.

Stewart, Michael (1993) 'Gypsies and the Work Ethic Under Socialism', in Hann, Chris (ed.), Socialism: Ideals, Ideologies, and Local Practices, New York, Routledge, pp. 187-203.

Todorov, R. (compiled by) (1940) Trânski kraj: Prinos kâm izucavaneto na zapadnite bâlgarski kraista [The area of Trun. A Contribution towards the study of the Western Bulgarian regions], Sofia, At the Author.

Todorova, Maria (1993b) Balkan Family Structure and the European Pattern. Demographic Developments in Ottoman Bulgaria, New York, The American University Press.

Todorova, Maria (1993a) 'Slava und Zadruga', Historische Anthropologie. Kultur-Gesellschaft-Alltag, Jhg. 1, Hft. 1, pp. 123-129 [Forum].

Valtchinova, Galia (1999) Znepolski pohvali: Iokalna religija i identičnost v Zapadna Bălgarija [Laudae Znepolensia: Local Religion and Identity in Western Bulgaria], Sofia, The 'Prof. M. Drinov' Academic Publishers.

Vryonis, Speros (1983) 'The Panegyris of the Byzantine Saint: a study in the nature of medieval institutions, its origins and fate', in Hackel, Sergei (ed.), The Byzantine Saint. University of Birmingham 14th Symposium of Byzantine Studies, San Bernadino, Borgo Press, pp. 196-226. 